\title{
APONTAMENTOS SOBRE A PSICOLOGIA ANALITICA DE CARL GUSTAV JUNG ${ }^{1}$
}

\section{Luís Marcelo Alves Ramos}

Resumo: O texto faz uma introdução à Psicologia Analítica do psicólogo e psiquiatra suíço Carl Gustav Jung: define o conceito de Psicologia Analítica, traz uma biografia resumida de Carl Gustav Jung, indica as principais diferenças entre a Psicologia Analítica e a Psicanálise, descreve a estrutura e o funcionamento da psique e, por fim, apresenta sinteticamente as características dos tipos de personalidades traçadas por Jung.

Palavras-chave: Psicologia Analítica; Psicanálise; Freud e Jung; Psique; Tipos psicológicos

\begin{abstract}
The text makes an introduction to the Analytical Psychology of the psychologist and swiss psychiatrist Carl Gustav Jung: it defines the concept of Analytical Psychology, brings a summarized biography of Carl Gustav Jung, indicates the main differences between Analytical Psychology and the Psychoanalysis, describes the structure and the functioning of psyche and, finally, presents synthetically the characteristics of the types of personalities traced by Jung.
\end{abstract}

Key words: Analytical Psychology; Psychoanalysis; Freud and Jung; Psyche; Psychological types

1. Aula ministrada em três módulos (dias 24/10, 31/10 e 07/11 de 2002) aos alunos do curso de graduação em Administração da UNOPEC (União das Faculdades da Organização Paulistana Educacional e Cultural) de Sumaré - SP. 


\section{DEFINIÇÃO DE "PSICOLOGIA ANALÍTICA"}

É um conjunto de conhecimentos (teoria) que procura investigar e explicar a estrutura e o funcionamento da psique e uma categoria de psicoterapia (prática) formulada inicialmente pelo psiquiatra e psicólogo suíço Carl Gustav Jung. Após sua morte, a Psicologia Analítica passa a receber reformulações pelos neojunguianos.

\section{Gênese:}

- Formulada por Carl Gustav Jung (psicólogo e psiquiatra suiço)

É um dos mais importantes pensadores da Psicologia Clínica

Sua obra científica está intimamente associada aos acontecimentos de sua própria vida e ao estudo de seus casos clínicos

- Início do séc. XX (oficialmente o termo Psicologia Analítica foi utilizado por Jung em 1913, porém, suas bases foram sendo geradas em alguns anos anteriores)

- É uma teoria / prática psicodinâmica (enfatiza os fatores internos da psique)

\section{A VIDA DE JUNG E O INÍCIO DA PSICOLOGIA ANALÍTICA}

- Nasce em 1875, em Keswill, na Suíça. Sua família é luterana. Seu pai é pastor.

- Desde criança chamam-lhe a atenção os estudos sobre a natureza (Biologia), $\mathrm{o}$ embate entre as ciências $\mathrm{e}$ as religiões, a idéia de "Deus" (sobretudo a contradição sobre a origem do bem e do mal), entre outros temas da Biologia, da Filosofia e da Teologia.

Jung foi uma criança bastante sensível e de uma sagacidade intelectual notável, o que, mesmo assim, não lhe poupou alguns dissabores, como um lar algumas vezes um pouco desestruturado e a inveja dos colegas, bem como a solidão.

- De 1895 a 1900 estuda Medicina na Universidade da Basiléia, Suíça.

- Em 1900 torna-se assistente de Eugen Bleuler no Burghölzli (hospital psiquiátrico), em Zurique, Suiça.

- Também em 1900 lê a obra "A interpretação dos sonhos" de Freud, o que lhe desperta interesse pela Psicanálise.

- Em 1902 defende sua Tese de Doutorado.

- De 1905 a 1909 é Chefe de Clínica no Burghölzli.

- De 1905 a 1913 leciona na Faculdade de Medicina de Zurique e atrai a inimizade de alguns acadêmicos ao defender algumas idéias (porém, nem todas) de Freud.

- Em 1907 dá-se seu primeiro encontro com Freud (a conversa dura 13 horas).

Jung é aceito no estreito círculo de psicanalistas de Freud.

- Em 1909 abre sua clínica particular.

- De 1910 a 1914 exerce o cargo de Primeiro Presidente da Associação Psicanalítica Internacional (pela vontade de Freud).

Freud considera-se como um pai de Jung (sem a concordância deste) e diz tomá-lo como seu "príncipe herdeiro". Já a partir de 1909 Jung (na ocasião de uma visita de Jung e Freud aos Estados Unidos a convite de universidades desse país) começa a expôr algumas de suas próprias idéias a Freud, que as considera "meras tolices". 
- Em 1913 Jung funda a Psicologia Analítica ao publicar uma obra ("Metamorfoses e símbolos da libido") em que expõe abertamente suas próprias idéias em grande parte contrárias à Psicanálise (entre alguns exemplos, acredita na importância da sexualidade na vida humana, porém, não a considera como o único $\mathrm{e}$ principal motivo propulsor da vida e das causas das doenças psíquicas; discorda do método de interpretação dos sonhos estruturado por Freud e formula seu próprio método; e critica a visão positivista de Freud sobre a Psicologia. Ao contrário deste, crê na importância da busca da espiritualidade e do papel das religiões para uma vida saudável). Devido a isso, Freud rompe o vínculo profissional e a amizade com Jung. Após esse fato nunca mais em suas vidas os dois trocariam palavras.

Para Paul Roazen, a fecunda e tumultuada amizade entre Freud e Jung é um dos marcos da história do pensamento e da cultura ocidental (várias obras foram publicadas acerca desse fato).

$\mathrm{O}$ rompimento dessa amizade impediu a continuação de uma parceria que poderia ter contribuído para um desenvolvimento ainda maior da Psicologia.

Durante alguns anos, após esse rompimento com Freud, Jung passará por um período de solidão pessoal e profissional. Os "amigos" do círculo psicanalítico (muitos deles mantinham inveja de Jung) se distanciam. Outros amigos (estes também dissidentes de Freud) conservam-lhe a amizade. Com o tempo, Jung formará seu próprio círculo de amigos e colaboradores (principalmente mulheres) que irá propagar a Psicologia Analítica pelo mundo.
- Por volta de 1915 inicia seus estudos sobre Gnose, Alquimia e Psicologia Oriental, donde retira elementos que doravante estarão sempre presentes na sua Psicologia Analítica.

- De 1918 a 1919 serve na Primeira Guerra Mundial como ComandanteMédico do campo de internação de soldados ingleses.

- Em 1923 termina a construção da "Torre de Bollingen" (uma construção, em moldes suíços antigos, perto do Lago de Zurique, onde "vivia seu verdadeiro eu").

Ainda nesse ano trava amizade com Richard Wilhelm (autor do "I Ching - o livro das mutações", prefaciado por Jung), filólogo e grande conhecedor da cultura chinesa. Jung receberá deste homem um amplo conhecimento sobre o budismo e o taoísmo.

- De 1924 a 1925 visita aldeias dos índios pueblos no Novo México (EUA). Trava contato com xamãs (chefes religiosos, homens sagrados), com os quais recebe conhecimentos sobre a filosofia, psicologia e religião desses povos.

- De 1925 a 1926 faz uma expedição à Uganda e ao Quênia (África). Conhece as nascentes do Rio Nilo. Visita tribos dos aborígenes Elgonys no Monte Elgon, onde aprende sobre a filosofia, psicologia e religião desses nativos.

- Em 1933 viaja ao Egito e à Palestina em busca de conhecimentos de outras culturas, que não a européia.

- Em 1934 é eleito Presidente da Sociedade Médica Geral para Psicoterapia.

- Em 1938 viaja à Índia a convite do governo britânico, onde conhece vários yogues, homens portadores do saber religioso da cultura hindu.

- Em 1944 é nomeado para lecionar na Faculdade de Medicina da Basiléia, 
numa cátedra de Psicologia especialmente criada para ele.

- Após o término da Segunda Guerra Mundial (1945) escreve sobre as origens psicológicas do nazismo. Seus inimigos políticos distorcem deliberadamente suas idéias e promovem uma intriga de vasta amplitude social acusando-o de ser simpatizante dos nazistas. Seus amigos de origem judia prontamente acorrem a seu favor e criticam publicamente aqueles que promoveram tal enredo.

- Em 1948 é inaugurado o Instituto Carl Gustav Jung, em Zurique.

- Em 1957 inicia a redação de sua autobiografia (intitulada "Memórias, sonhos e reflexões". É editada, a pedido de Jung, após sua morte).

- Morre em 1961, aos 86 anos, em sua casa à beira do lago, em Zurique, Suiça.

Durante sua vida, recebeu vários títulos de doutor honoris causa.

Deixou um vasto legado para a Medicina, a Psicologia, a Antropologia e as demais ciências humanas condensado numa obra científica de 18 volumes, além de outros importantes escritos (incluindo sua autobiografia). É um dos pensadores mais importantes da história da humanidade. Não só um pensador, um cientista, mas um homem sábio.

\section{OBSERVAÇÕES INICIAIS}

Em sua autobiografia ("Memórias, sonhos e reflexões") Jung diz que, quando criança, sentia possuir duas personalidades: um "eu" público, exterior, envolvido com seu mundo familiar, e um "eu" secreto, que tinha uma proximidade especial com a natureza e com "Deus".
O sentimento de necessidade da integração entre esses dois "eu" (um voltado para o mundo exterior e outro para o mundo interior) incitou seu empenho pela busca do conhecimento de "si mesmo", daí seu interesse pela Psiquiatria e pela Psicologia.

Jung desde cedo, por um lado, questionou a validade de uma fé cega (que via em seu pai, um pastor luterano), que não permite o questionamento de seus dogmas e, por outro, também questionou a legitimidade de uma ciência de cunho positivista ("objetiva"), que não considera a importância da experiência "espiritual".

Procurando romper com essa dicotomia (contradição) entre o conhecimento religioso e o científico, Jung procurou na sua vida e obra apresentar a possibilidade de uma relação dialética (de "troca", interação) entre esses dois saberes (antagônicos, para muitas pessoas).

Ao longo de sua vida experimentou sonhos e visões de notáveis características mitológicas e religiosas, os quais despertaram o seu interesse por mitos, sonhos, alquimia e a psicologia da religião (ocidental e oriental): religiões pré-cristãs, cristianismo (catolicismo, protestantismo e gnosticismo), islamismo, budismo, hinduísmo, taoísmo, xamanismo, entre outras religiões.

A par dessas experiências, certos fenômenos parapsicológicos emergiram na sua vida, sempre redobrando seu espanto e questionamento.

Também travou amizades e diálogos com personagens célebres da história nos campos da ciência, da política, da economia e das artes. Contudo, conforme relata na sua autobiografia, poucos desses encontros the representaram algo 
marcante. As pessoas que mais lhe despertaram o interesse e com as quais mais aprendeu sobre os "segredos" da vida em geral foram as personagens anônimas, desconhecidas do público em geral, que passaram por seu consultório.

É desse amplo leque de estudos e vivências que Jung estruturou sua Psicologia Analítica, procurando, a par da produção de sua obra científica, viver ele mesmo sua busca pelo conhecimento se "si mesmo", pelo crescimento "espiritual".

\section{FREUD E JUNG}

Por volta de 1900 Jung interessou-se pela Psicanálise ao ler "A interpretação dos sonhos" de Freud.

Em 1907 deu-se o primeiro encontro entre Freud e Jung (uma conversa que durou treze horas).

Inicialmente Freud tomou Jung como "seu filho, seu príncipe herdeiro", fazendo, inclusive, que Jung se tornasse o primeiro Presidente da Associação Psicanalítica Internacional (1910-1914).

Entretanto, apesar de defender algumas idéias de Freud (o que lhe valeu inimizades no mundo acadêmico com uma consequiente dispensa da docência na Faculdade de Medicina de Zurique), Jung possuía ideais próprios, muitos dos quais foram considerados por Freud como "meras tolices".

Em 1910 Jung ao editar seu livro "Metamorfoses e símbolos da libido", em que expõe diversas idéias contrárias à Psicanálise, tem como reação de Freud a ruptura de suas relações profissionais e de suas amizades.
Após esse fato nunca mais nas suas vidas voltariam a trocar palavras (Freud faleceu em 1939, aos 83 anos).

\section{APONTAMENTOS SOBRE AS PRINCIPAIS DIFERENÇAS ENTRE A PSICANÁLISE (FREUD) E A PSICOLOGIA ANALÍTICA (JUNG)}

\section{A origem do inconsciente}

Freud : - a criança nasce uma tábula rasa, um ser "vazio", meramente biológico (animal), sem psiquismo. $\mathrm{O}$ inconsciente surge $a$ posteriori ao nascimento a partir da "primeira mamada", sendo um mero depositário de recalques, de desejos sexuais (pulsões). No dizer de Freud, o inconsciente pode apenas desejar (sexualmente).

Jung : - Jung faz a distinção entre inconsciente pessoal e inconsciente coletivo.

$\mathrm{O}$ inconsciente pessoal surge a posteriori ao nascimento como resultado das experiências de vida do indivíduo (assemelha-se às noções de pré-consciente $\mathrm{e}$ inconsciente da Psicanálise).

$\mathrm{O}$ inconsciente coletivo surge a priori ao nascimento. É herdado de forma psicológica e biológica, nasce com a criança. É, portanto, um material inato da psique. É formado pelos arquétipos, núcleos instintivos, passados de geração a geração (psíquica e biologicamente). 
Obs.: - Para Freud o inconsciente interfere no comportamento no sentido da busca da satisfação das pulsões (desejos sexuais) advindas do $i d$, bem como na "censura" dessa satisfação.

Para ele, o ego (núcleo da consciência) não pode modificar a natureza do inconsciente.

- Para Jung o inconsciente (pessoal e coletivo) interfere no comportamento não só no sentido de empenho da satisfação do prazer sexual, mas, também, através de mecanismos de sobrevivência, de procura de satisfação afetiva e social, de desenvolvimento pessoal, de busca do conhecimento de si mesmo e da experiência numinosa (ver obs. seguinte). Para ele, há uma relação dialética (de "trocas" de energia psíquica - libido) entre o eu (núcleo do consciente) e o inconsciente, dada pelo processo de individuação (busca da vivência do "si mesmo"), em que ambos se transformam, possibilitando que o indivíduo vivencie um estado de "totalidade" psíquica.

No entanto, a vivência do $s i$ mesmo é uma possibilidade e não um destino. O processo de individuação pode ou não ser levado a cabo (isso depende das condições internas (psíquicas) e externas (sociais) nas quais se encontra o indivíduo).
- Jung empresta o termo numinosidade de Rudolf Otto (1869-1927), teólogo e filósofo alemão, que caracteriza o numinoso como um sentimento único (de integração, de comunhão, com o universo) vivido na experiência religiosa, a experiência do sagrado (que dá sentido à vida e à morte).

\section{O conceito de libido}
Freud : - conceitua a libido como energia psíquica (que movimenta o psiquismo humano) de natureza unicamente sexual.

Jung : - conceitua a libido como energia psíquica (energia vital) que inclui não apenas a sexualidade, mas, também, outros elementos: instintos de sobrevivência (sede, fome, agressividade, necessidade de proteção física, etc.), a busca de relações afetivas e sociais, do desenvolvimento pessoal, do conhecimento de si mesmo e da experiência numinosa.

Obs.: - Jung aponta que para muitas pessoas a vivência da sexualidade e a busca espiritual são consideradas como algo antagônico (contraditório) uma vez que tais pessoas associam a sexualidade ao pecado (algo, então, contrário à espiritualidade). Nesse ponto, 
Jung indica que uma vida saudável (não neurótica) permite a integração entre a sexualidade e a espiritualidade. Tanto a vivência de uma sexualidade satisfatória como da experiência espiritual é necessária ao equilíbrio (homeostase) psicofisiológico.

\section{A origem da doença psíquica}

Freud : - a doença psíquica tem sua origem em traumas sexuais sofridos na infância.

Jung : - a doença psíquica tem sua origem numa exacerbada dissociação entre elementos do consciente e do inconsciente (contradições internas experienciadas pelo sujeito) que impede a vivência da totalidade psíquica (essa dissociação pode ou não ter um fundamento de natureza sexual).

\section{Método psicoterápico}

Freud : - uso da associação livre, interpretação de sonhos, valorização da relação transferencial e do diálogo através da utilização do divã.

Jung : - uso da associação livre e da imaginação ativa, interpretação de sonhos, produção de desenhos, valorização da relação transferencial e do diálogo face a face.

Em estudos sobre a sincronicidade (ver a explicação do conceito mais adiante) Jung também utilizou o oráculo do I Ching em consultas (mediante autorização do paciente e o uso de uma metodologia científica rigorosa para analisar as experiências realizadas com o oráculo).

Obs.: - Embora Freud e Jung utilizassem apenas a modalidade de psicoterapia individual, na atualidade, tanto Psicanalistas como Psicólogos Analíticos, além de fazerem uso da psicoterapia individual, também fazem uso da psicoterapia em grupo.

\section{Teoria do desenvolvimento da personalidade}

Freud : - Freud, além de formular um modelo de estrutura da psique (1 $1^{\underline{a}}$ e $2^{\underline{a}}$ tópicas) e explicar seu funcionamento (instâncias econômica, tópica e dinâmica), também elabora uma teoria do desenvolvimento da personalidade (períodos prégenital, de latência e genital)

Jung : - Jung formula um modelo de estrutura da psique (consciente e inconsciente pessoal e coletivo), porém, não elabora uma teoria do desenvolvimento da 
personalidade da infância à fase adulta. Seus estudos enfatizam o desenvolvimento da personalidade a partir da idade adulta.

Esse é um ponto em que Jung deixa uma "lacuna" na sua Psicologia Analítica por não ter reconhecido a importância de determinados aspectos da teoria do desenvolvimento da personalidade de Freud.

A formulação de uma teoria de base junguiana do desenvolvimento da personalidade que engloba a infância à maturidade coube aos neo-junguianos que, ironicamente,

fundamentaram-se na Psicanálise para elaborá-la (porém, não na Psicanálise ortodoxa de Freud, mas na releitura da Psicanálise de Mellanie Kleine).

\section{Teoria da interpretação dos sonhos}

Freud : - o sonho é um mecanismo psíquico de expressão encoberta das pulsões (desejos sexuais) e de sua gratificação parcial.

Uma vez que o indivíduo não pode satisfazer determinadas pulsões na sua vida, o sonho atua como um mecanismo psíquico que permite que a satisfação dessas pulsões seja parcialmente realizada, evitando possíveis sofrimentos psíquicos (por exemplo, neuroses).

O sonho possui um conteúdo manifesto (imagens e mensagens envolvidas por mecanismos de simbolização e distorção que visam "censurar" a expressão das pulsões) e outro latente (encoberto pelo conteúdo manifesto, representa a expressão das pulsões).

Assim, para Freud, o conteúdo simbólico do sonho mascara o que ele quer realmente "dizer" (a expressão das pulsões, dos desejos sexuais).

Jung : - o sonho é um mecanismo
psíquico que revela um
"mapa" do desenvolvimento
da personalidade na busca
(consciente ou inconsciente)
da vivência do si mesmo
(processo de individuação).
Não esconde o que quer
"dizer". Muito pelo contrário,
expressa realmente o que
quer expressar, porém,
através de símbolos.
Ao contrário do que
sustentava Freud ao dizer que
os símbolos escondem o real
significado dos sonhos (a
expressão de pulsões, desejos
sexuais), Jung acredita que os
símbolos exprimem o real
significado dos sonhos (um
"mapa" do processo de
individuação).

\section{Religiosidade}

Freud : - Freud fundamenta a Psicanálise a partir de uma filosofia positivista, que toma como legítima apenas as ciências cartesianas, "objetivas". Assim, não há 
espaço para a vivência da religiosidade na Psicanálise.

A concepção de Deus para Freud é associada à procura pelo indivíduo da figura do "pai protetor da infância": a imagem do "pai protetor" de sua infância é projetada na figura de Deus.

Jung : - Jung considera importante para a saúde psíquica a vivência da religiosidade (entendida como numinosidade), da busca espiritual.

Segundo ele, o processo de individuação está associado à vivência dessa numinosidade. Em alguns de seus escritos informais (cartas e autobiografia), Jung revela a importância que dava à busca de Deus (Jung entendia Deus como uma "consciência e inconsciência cósmica", como a "natureza" e não como um "ser" criador dissociado de sua criação. A concepção de Deus de Jung assemelha-se à concepção de Deus de algumas doutrinas cristã-gnósticas).

Nas suas obras científicas Jung nunca fala de Deus, mas da imagem de Deus na alma. Isto não constitui uma contradição: por um lado, sua afirmação é subjetiva, baseada numa vivência e, por outro, é uma constatação científica e objetiva.

No primeiro caso, é o homem religioso que fala, o homem cujos pensamentos são influenciados por sentimentos poderosos e apaixonados, por intuições e experiências interiores e exteriores de uma vida longa e fecunda. No segundo, é o cientista que toma a palavra, e suas afirmações não ultrapassam os limites do conhecimento científico, restringindo-se

conscientemente a fatos demonstráveis.

Portanto, na sua obra científica Jung nunca procurou provar a existência objetiva de Deus, mas demonstrou que no plano da subjetividade a vivência do numinoso é possível e constitui um fator fundamental para a saúde psíquica .

\section{Paranormalidade}

$$
\begin{aligned}
\text { Freud : - } & \text { possuía uma filosofia } \\
& \text { positivista sobre a vida e a } \\
& \text { ciência. Por essa razão, nutria } \\
& \text { receio e distância em relação } \\
& \text { aos fenômenos paranormais. }
\end{aligned}
$$

Jung : - durante toda sua vida experienciou certos fenômenos paranormais (extra-racionais). Também levava em alta consideração as situações de paranormalidade vivenciadas por seus pacientes. Por tais motivos, sustentou um interesse especial pelo estudo desses fenômenos (particularmente pela sincronicidade, um conceito por ele criado e que será explicado mais adiante). 


\section{Teoria do desenvolvimento cognitivo/afetivo e da aprendizagem}

Tanto Freud como Jung não formularam uma teoria sobre o desenvolvimento cognitvo/afetivo e da aprendizagem.

$\mathrm{Na}$ história da Psicologia os grandes expoentes da produção de teorias do desenvolvimento cognitivo e da aprendizagem são o biólogo francês Jean Piaget (Teoria psicogenética) e o psicólogo soviético Lev Vigotsky (Teoria Sócio-Histórica).

Vigostsky também traz contribuições para a formulação de uma teoria sobre o desenvolvimento afetivo. Entretanto, o desenvolvimento dessa teoria ganha mais peso com determinadas vertentes teóricometodológicas da Psicologia Social.

\section{Gênese social da doença mental}

Uma das críticas freqüentes à Psicanálise e à Psicologia Analítica está relacionada à "psicologização" ("tudo é psicológico") das causas das doenças psíquicas. Em suas elaborações iniciais, estas duas teorias/práticas consideram apenas como gênese das doenças mentais os fenômenos decorrentes de elementos internos do indivíduo (fatores psicológicos e biológicos) sem considerarem a influência do meio social (contexto social, econômico, político, histórico, cultural e geográfico em que o indivíduo está inserido) como possível causa desses distúrbios.

Tais críticas vêm de áreas do conhecimento como a Psicologia Social, a Antropologia, a Esquizoanálise, entre outras.

Se por um lado a crítica é legítima, pois, de fato, as doenças mentais têm em grande parte causas sociais, por outro, devemos considerar que tanto Freud como Jung foram pioneiros no desenvolvimento do conhecimento psicológico e construíram suas teorias com base nos saberes e limites teóricometodológicos até então dados em suas épocas.

Assim, embora Freud e Jung tenham deixado "lacunas" em suas teorias (algo inerente ao trabalho de qualquer cientista), não se pode de forma alguma negar a importância da produção do conhecimento por eles deixados.

Nesse ponto é importante enfatizar que tanto a Psicanálise como a Psicologia Analítica receberam reformulações de outros cientistas (psicanalistas, esquizoanalistas, psicólogos neojunguianos, psicólogos sociais, antropólogos e sociólogos) que consideram a importância da influência social na gênese e desenvolvimento das doenças psíquicas.

\section{ESTRUTURA DO APARELHO PSÍQUICO (PSIQUE)}

Para Jung a psique está estruturada em três elementos:

\section{CONSCIENTE}

- Tem como núcleo o "eu" (assemelhase ao ego psicanalítico).

- Sistema do aparelho psíquico que mantém contato com o mundo interior (processos psíquicos, internos) e exterior (meio ambiente, sociedade) do sujeito.

- Na consciência destacam-se os mecanismos de percepção, de atenção, de memória e de raciocínio.

- As pessoas são conscientes apenas de uma pequena parcela de sua vida psíquica. 


\section{INCONSCIENTE PESSOAL}

- Formado pelas camadas mais superficiais do inconsciente.

- Sistema onde permanecem os conteúdos inconscientes derivados da vida do indivíduo (sua formação é, portanto, a posteriori ao nascimento). Geralmente não possuem energia psíquica suficiente para permanecerem no campo da consciência: conteúdos de experiências de vida, conflitos psicológicos (denominados por Jung de "complexos") e desejos pessoais (sexuais ou não) não realizados.

- Alguns de seus conteúdos podem adquirir energia psíquica suficiente para irromperem na consciência. Isso ocorre através de lembranças, sonhos e fantasias.

\section{INCONSCIENTE COLETIVO}

- Formado pelas camadas mais profundas do inconsciente.

- Constituído por elementos denominados de arquétipos.

- Os arquétipos são núcleos instintivos passados de forma psicobiológica de geração a geração (a gênese do inconsciente coletivo é, portanto, a priori ao nascimento. A criança já nasce com ele). Trazem padrões de comportamento herdados da humanidade desde seu surgimento.

Ex.: Um exemplo clássico é quando um indivíduo vivencia uma situação de perigo e age de forma inusitada (um padrão de comportamento não esperado) para se desvencilhar dela.

Não é raro ouvirmos de pessoas que passaram por situações dessa natureza dizerem "Não sei como consegui fazer 'aquilo' para conseguir sair daquela situação!”.
Se agisse de forma refletida, consciente, através apenas dos mecanismos psicológicos do $e u$, talvez a pessoa não conseguiria ter saído de tal situação de perigo.

O que ocorre é que um arquétipo tomou conta da consciência (subjugando, eclipsando, o eu) e fez com que o sujeito agisse de forma inconsciente para desvencilhar-se do perigo.

Nesse caso, tal arquétipo traz em si as experiências da humanidade (desde sua origem) que guardam um conhecimento sobre o "escapar de um perigo".

A situação de perigo fez com que esse arquétipo fosse ativado, fazendo com que o indivíduo agisse inconscientemente para escapar da situação.

- Os arquétipos são inúmeros, incontáveis, porém, Jung nomeia alguns que estão em permanente contato com o eu. São eles: a persona, a sombra, a anima, o animus e o self este também é denominado de si mesmo e constitui o núcleo central não só do inconsciente, mas, também, de toda a psique (será falado sobre a natureza desses arquétipos mais adiante).

- A camada mais profunda do inconsciente coletivo é denominada de Psicóide. Esta camada se relaciona aos acontecimentos que ultrapassam as explicações cientificamente objetivas sobre as relações causais entre fenômenos psíquicos e físicos. Tais fenômenos possuem uma ligação causa-efeito que desafiam as explicações da física clássica acerca de determinadas relações entre a psique, o espaço e o tempo.

São manifestações da Psicóide: sonhos e visões premonitórias (precognição), 
percepção extra-sensorial (PES), fenômenos de sincronicidade ("coincidências" que na realidade não são bem "coincidências"), telecinésia (movimentação e materialização de objetos sem contato físico), desdobramento astral, visão áurica, combustão espontânea (a pessoa incendeia-se através de um "fogo frio" que surge espontaneamente, sem causas externas, consumindo apenas a pessoa e nada mais ao seu redor. Os parapsicólogos relacionam esse fenômeno ao desejo de autodestruição, de suicídio).

- Esses fenômenos são estudados pela Parapsicologia. Jung interessou-se particularmente pelo estudo da sincronicidade (um conceito criado por ele e também estudado por Wolfgang Pauli, um físico agraciado com o Prêmio Nobel de Física. Jung escreveu um livro em que relata e defende a existência de fenômenos de sincronicidade).

No campo da Física, é a Física Quântica que estuda estes fenômenos. Recentemente estas manifestações estão sendo objeto de estudo de vários médicos (estudam a natureza dos "milagres" e da influência da religiosidade na cura das doenças psíquicas e fisiológicas).

\section{Manifestações do inconsciente (pessoal} e coletivo):

- comportamento (grande parte de nossas condutas é inconsciente, escapa à ação do nosso eu)

- sonhos

- fantasias

- atos falhos

- lapsos de linguagem

- lembranças

- desenhos

- doenças mentais
- fenômenos paranormais (extraracionais)

Obs.: considerando que passamos um significativo tempo de nosso dia dormindo (de 1/3 a 1/5 dele), então, passamos uma boa parte de nossa vida em estado de inconsciência (ou seja, de 1/3 a $1 / 5$ dela). Isso sem contar as interferências do inconsciente na consciência durante nosso estado de vigília.

Os elementos do inconsciente (pessoal e coletivo) podem ser ativados através de:

- situações cotidianas (as mais diversas)

- memória

- sono

- psicoterapia (associação verbal, associação livre, hipnose, imaginação ativa, transferência, produção de desenhos, uso de brinquedos, etc.)

- expressões artísticas

- rituais 


\section{Diagrama do aparelho psíquico (psique)}

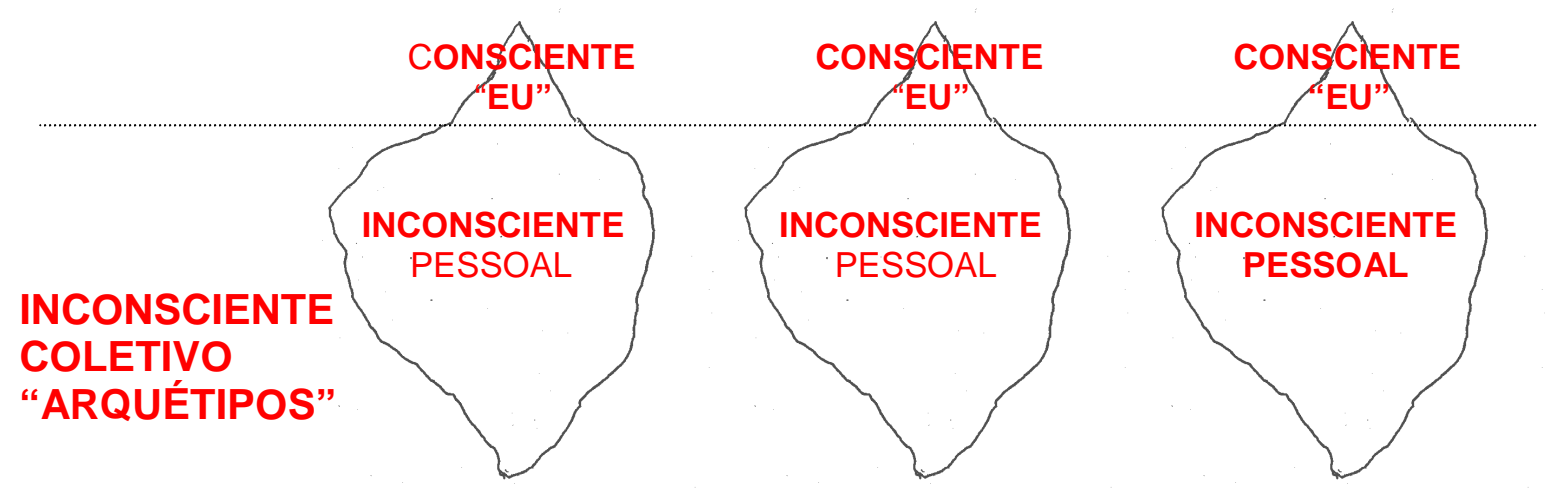

O núcleo central da psique (consciente e inconsciente) é o "self"

Obs.: no diagrama, o indivíduo é representado por um iceberg

Consciente: é a ponta do iceberg da psique. Tem como núcleo central o $\mathrm{eu}$. Geralmente uma pequena parcela de nossas ações é consciente. A maior parte é inconsciente (mesmo no estado de vigília e, principalmente, no estado de sono - passamos de $1 / 3$ a $1 / 4$ de nossas vidas dormindo, ou seja, em estado de inconsciência).

Inconsciente pessoal: é a base do iceberg da psique. É a camada mais superficial do inconsciente, a parcela do inconsciente própria de cada pessoa.

Inconsciente coletivo: é o mar, onde se encontram os icebergs (na prática, o inconsciente coletivo realmente muitas vezes se manifesta nos sonhos assumido a imagem do mar, do oceano). É formado pelos arquétipos. Todas as pessoas (os icebergs) têm acesso aos conteúdos (arquétipos) do inconsciente coletivo (pois estão "mergulhadas" nele), ao mesmo tempo em que "ele" se expressa em todas as pessoas.

O inconsciente coletivo é o "elo" da psique que une toda a humanidade (e, também, os demais animais, pois estes também estão "mergulhados" no inconsciente coletivo), tal como os genes são os "elos" que unem biologicamente os seres viventes.

A idéia de um elo comum (psíquico e biológico) entre todas as coisas viventes já era expressa nas primeiras religiões da história da humanidade através dos mitos (e ainda o é nas religiões atuais). Hermes Trismegistus, fundador do hermetismo, uma antiga religião egípcia, por exemplo, dizia que "tudo é uma coisa só".

Em muitas religiões o inconsciente coletivo é tomado como a figura de Deus.

Essa idéia também é expressa muitas vezes nas artes. Em "O império do Sol", 
por exemplo, a personagem principal do filme faz um questionamento sobre Deus que remete à idéia do inconsciente coletivo: "Quem sabe se ele não é nossos sonhos e nós o dele !?"

\section{ARQUÉTIPOS}

Tal como havia mencionado anteriormente, os arquétipos constituem o inconsciente coletivo. Tratam-se de núcleos instintivos passados de forma psicobiológica de geração a geração, trazendo padrões de comportamento herdados da humanidade desde seu surgimento.

São inúmeros os arquétipos, porém, Jung nomeia alguns que estão permanentemente presentes nas nossas vidas, influenciando de forma inconsciente nossas condutas: a persona, a sombra, a anima, o animus e o self (si mesmo). Os arquétipos geralmente encobrem, eclipsam, a ação do eu. Achamos que somos "senhores de nós mesmos", "senhores de nossas ações e de nossos desejos", mas, na maioria das vezes, não somos. Outros "eu" (os arquétipos) freqüentemente direcionam nossos pensamentos, sentimentos e ações. E embora ao tomarmos consciência de suas existências possam parecer estranhos a nós, fazem parte de nós, queiramos ou não.

\section{A persona}

- Persona é um termo emprestado por Jung do teatro grego antigo, que designava as "máscaras" (várias personagens) desempenhadas pelos artistas.

- É um arquétipo de adaptação ao meio social, necessário à vida em sociedade.

- Não corresponde à personalidade verdadeira do indivíduo (Jung denomina a personalidade de alma - não no sentido espiritual). A persona está associada às "máscaras" que utilizamos para desempenhar papéis sociais que não correspondem realmente à nossa alma (personalidade).

- A persona pode agir de forma autônoma, ou seja, o indivíduo passa agir como uma "máscara", a desempenhar comportamentos que não condizem realmente com sua personalidade. A persona representa o que a sociedade espera do indivíduo em termos de desempenho de papéis sociais.

- Por ser um arquétipo, exercendo geralmente um papel autônomo na consciência (ofuscando a visão do $e u$ ), é mais frequiente que o indivíduo não tenha consciência da existência de sua persona.

Possui dois aspectos:

- positivo : pode propiciar a adaptação do indivíduo ao meio social, sem prejudicar a expressão das qualidades de sua alma (personalidade).

Ex.: $\mathrm{O}$ indivíduo passa a exercer

determinado cargo profissional (que exige o desempenho de determinados papéis) sem deixar de ser a pessoa "que era anteriormente".

- negativo : ocorre quando o eu identifica-se com a persona, desconsiderando os reais elementos da psique que constituem 
sua personalidade. Nesse caso, o indivíduo passa a ser uma "máscara", uma "impostura".

Ex.: A pessoa ao passar a exercer determinado cargo profissional passa a ser "mascarada". Deixa de "ser a mesma pessoa que era antes".

\section{A sombra}

- Trata-se de um arquétipo (geralmente desconhecido do $\mathrm{eu}$ ) que tende a ser projetado nos outros. Esse arquétipo esconde nossas virtudes e defeitos.

Possui dois aspectos:

- positivo : esconde qualidades positivas, virtudes, as quais o próprio indivíduo não possui consciência.

$\begin{aligned} \text { Ex.: } & \text { Pessoas que } \\ & \text { praticam } \\ & \text { determinadas } \\ & \text { atividades altruístas } \\ & \text { sem se darem conta } \\ & \text { do valor social } \\ & \text { dessas ações. }\end{aligned}$

- negativo : é o lado "sombrio", "negro" do ser humano que tende a ser projetado nos outros.

Ex.: A pessoa julga uma outra de invejosa quando é ela mesma que o é.

Aqui se incluem todos os gêneros de qualidades

negativas da "alma" humana: inveja, egoísmo, ciúme doentio, ódio, mesquinhez, mentiras,

falsidades, entre outras.

\section{Obs.:}

- Sendo um arquétipo (um elemento da psique coletiva) a sombra não raras as vezes manifesta-se de forma coletiva através de comportamentos impulsivos e agressivos.

Ex.: Por exemplo, quando sai brigas em partidas de futebol, ocorre o que na Psicologia é nomeado de “contágio psíquico". Muitos torcedores agem inconscientemente de forma impulsiva e agressiva, fazendo coisas que não fariam em seu "perfeito juízo" (a menos que seja um psicopata, que age deliberadamente de forma agressiva).

Nesse caso, o eu (o elemento da consciência que pondera sobre os atos do indivíduo através do uso da razão) de cada torcedor é eclipsado pela sombra (o lado "negro,", "sombrio" da natureza humana) que se manifesta, nesse caso, de maneira coletiva e em forma de agressão.

É por isso que um indivíduo sozinho pode ser incapaz de exprimir certos atos violentos que consegue tranquiilamente produzir em grupo. O grupo detém o poder de potencializar a manifestação da sombra (ofuscando o eu, o uso da razão, da pessoa).

Aqui se inscrevem, por exemplo, os atos de linchamento (alguém diz "Pega, lincha!" e as pessoas partem para um ato de linchamento). 
Mas, ao contrário dos exemplos acima dados, o grupo também pode ter a faculdade de potencializar os aspectos positivos da sombra de seus membros. É o que acontece quando uma pessoa se integra a um grupo de voluntários e descobre nela mesma virtudes que antes lhe eram desconhecidas (deixo bem claro que não estou considerando os aspectos políticos que envolvem os movimentos de voluntários. Não se trata aqui de questionar se ser voluntário é politicamente correto ou não. Estou pondo a parte essa questão e atendo-me apenas ao relato de um fato que pode bem exemplificar a expressão de virtudes coletivas da sombra. Detenho-me apenas em uma questão psicológica que pode se relacionar (ou não) aos movimentos de voluntários. Não é minha intenção entrar no julgamento das implicações sociológicas e políticas que se associam a tais movimentos).

\section{A anima}

- É a personificação da natureza feminina do inconsciente masculino.

- No homem seu consciente é masculino, porém, seu inconsciente é de natureza feminina (dominado pela anima).

- A primeira projeção da anima é na figura da mãe (ou de uma irmã). Por esse motivo, o homem que se torna uma presa de sua anima irá procurar uma companheira (namorada, esposa ou amante) com as características de sua mãe ou irmã (isso ocorre de forma inconsciente uma vez que a anima é um arquétipo - que encobre, portanto, a capacidade de visão do $e u$ ).
- Se por um lado as decisões conscientes do homem (geradas e geridas pelo eu) possuem características racionais, não emotivas, por outro, suas atitudes inconscientes (pela ação da anima) possuem um padrão sentimental, emotivo (mas de natureza arcaica e infantil).

- O homem geralmente acredita que é a razão que domina sua vida, porém, são os sentimentos, as emoções.

Possui dois aspectos:

- positivo : o homem que toma consciência de sua anima, dos aspectos femininos de sua psique, tem muito mais recursos para lidar com seus próprios sentimentos e, assim, com a mulher e com as pessoas de maneira geral.

a anima também permite ao homem a escolha de seu "par ideal".

- negativo : o homem que não toma consciência de sua anima, torna-se prisioneiro dela (uma vez que o $e u$ fica subjugado pela anima). Quando a anima subjuga o eu pode expressar-se na forma de "paixão cega", dependência, ansiedade, mudanças de humor, caprichos, irritabilidade, angústia, depressão, melancolia e mesmo (tentativa de) suicídio.

Ex.:

Quando um homem se "apaixona loucamente" por uma mulher (pessoa 
em que a anima é projetada) costuma-se dizer que "Ela virou-lhe a cabeça".

Quando uma mulher rompe o relacionamento com um homem, no caso de ele ainda desejá-la, não raramente ele "perde a cabeça” (desespera-se, reage com condutas infantis, entra em estados de angústia, melancolia e depressão e, em casos extremos, reage com agressividade e, mesmo, recorre ao suicídio - ou à sua tentativa). Tais condutas não condizem com a característica racional que domina a consciência masculina, são, sim, condutas de natureza emotiva, reflexos da ação da anima.

\section{O animus}

- É a personificação da natureza masculina do inconsciente feminino.

- Na mulher seu consciente é feminino, porém, seu inconsciente é de natureza masculina (dominado pelo animus).

- A primeira projeção do animus é na figura do pai (ou de um irmão). Por esse motivo, a mulher que se torna uma presa de seu animus irá procurar um companheiro (namorado, esposo ou amante) com as características de seu pai ou irmão (isso ocorre de forma inconsciente uma vez que o animus é um arquétipo - que encobre, portanto, a capacidade de visão do $e u$ ).

- Se por um lado as decisões conscientes da mulher (geradas e geridas pelo eu) possuem características emotivas, sentimentais, por outro, suas atitudes inconscientes (pela ação do animus) possuem um padrão racional (mas de natureza arcaica e infantil).

- A mulher geralmente acredita que são os sentimentos que dominam sua vida, porém, é a razão.

Possui dois aspectos:

- positivo : a mulher que toma consciência de seu animus, dos aspectos masculinos de sua psique, tem muito mais recursos para lidar com suas reflexões e, assim, com o homem e as pessoas de maneira geral.

o animus também permite à mulher a escolha de seu "par ideal".

- negativo : a mulher que não toma consciência de seu animus, torna-se prisioneiro dele (uma vez que o eu fica subjugado pelo animus). Quando o animus subjuga o eu pode expressar-se na forma de dependência, subserviência, juízos irrefletidos, preconceitos infundados, certezas não fundamentadas, "teimosias".

Ex.:

Numa crise de relacionamento num casal é mais freqüente que a mulher mantenha a "cabeça no lugar" (devido ao aspecto racional do animus). 
Quando uma mulher rompe o relacionamento com um homem, no caso de ela ter uma personalidade impulsiva, não raramente o faz com uma "frieza" que não deixa escapar qualquer ponta de afetividade (uma manifestação do animus).

Uma mulher com um animus muito proeminente acredita sempre ter a certeza de tudo, quer sempre ter a "última palavra". É frequiente se ouvir de uma mulher com essa característica a frase " $\mathrm{O}$ que eu posso fazer se eu sempre tenho a razão !?”

\section{Obs.:}

- A relação entre um homem e uma mulher é uma relação de complementaridade não só fisiológica (através da sexualidade) mas também psíquica (nesse caso, é uma relação quaternária de oposição e complementaridade, pois no plano consciente o eu masculino e o eu feminino se atraem. E no plano inconsciente anima e animus se atraem).

Essa relação psíquica de oposição e complementaridade é conhecida há muitos séculos pela psicologia oriental, expressando-se no símbolo do TAO (a oposição e a complementaridade entre os princípios Yin e Yang).

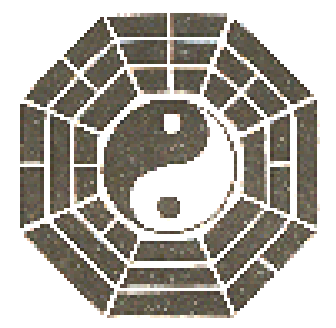

- O relacionamento entre um homem e uma mulher é sempre conflituoso devido às diferenças psicológicas conscientes (entre o eu masculino e o $e u$ feminino) e inconscientes (entre a anima e o animus), mesmo em casais que vivem em uma boa harmonia.

- Quando essa relação quaternária não é satisfatória (para um membro do casal ou para os dois) mais cedo ou mais tarde desemboca na(s) neurose(s) ou no seu rompimento.

\section{O self (si mesmo)}

- É o núcleo não só do inconsciente, mas, também, de toda a psique.

- É o arquétipo que leva o homem à busca pelo conhecimento de si mesmo, pelo autoconhecimento, pela integração com os demais homens, pela vivência espiritual, pela integração com Deus.

Essa busca é denominada por Jung de processo de individuação (será falado sobre esse conceito mais adiante) e trata-se da busca pela totalidade psíquica (a integração entre consciente e inconsciente).

- A vivência do self está associada à numinosidade.

Possui dois aspectos:

- positivo : sua vivência traz o sentimento de totalidade psíquica, de que existe um "elo" entre os homens, a natureza e Deus.

sua vivência traz um sentimento de sentido à vida e à morte.

- negativo : a pessoa que vivencia o self sem integrá-lo de forma consciente ao $\mathrm{eu}$ 
torna-se presa de seu lado negativo. Disso surgem os mais variados tipos de doutrinadores e fanáticos religiosos que querem impôr suas "verdades" aos outros.

\section{O PROCESSO DE INDIVIDUAÇÃO}

- O eixo central da Psicologia Analítica é o processo de individuação. Trata-se da busca do ser humano pelo conhecimento de si mesmo, pelo autoconhecimento, pela integração com os demais homens, pela vivência espiritual, pela integração com Deus.

Trata-se da busca pela totalidade psíquica (a integração entre consciente e inconsciente).

O impulso a essa busca é uma herança psicofisiológica passada de geração a geração através do arquétipo self. É, portanto, uma herança da humanidade a todas as pessoas. É algo inato no ser humano.

- A vivência do self está associada à numinosidade (vivências religiosas significativas que trazem sentido à vida e à morte).

- A vivência do self pode ser alcançada mediante uma busca própria (nesse caso, o indivíduo aprende através de suas próprias experiências, "acertando" e "errando", enfrentando seus "anjos" e "demônios". É a forma mais difícil (sofrida) de vivência do self), mediante o recurso da psicoterapia (nesse caso, ele terá o auxílio de outra(s) pessoa(s) na sua busca. A função da psicoterapia para Jung é auxiliar o indivíduo no seu caminho pelo processo de individuação) ou mediante a sua inclusão em instituições religiosas (que propiciem a vivência da numinosidade, ainda que inconscientemente. Jung faz a distinção entre "religião" enquanto instituição política, que não propicia a experiência do numinoso, da "religião" enquanto veículo de vivência do numinoso. Esse último aspecto diz respeito ao sentido correto do termo "religião" (do latim re ligare, ou seja, "religar", "reestabelecer" a integração entre o homem e Deus).

É de fundamental importância dizer que uma grande parcela da humanidade não atinge a meta final do processo de individuação (a vivência do self). $\mathrm{Na}$ verdade, muitos estagnam-se logo de início, nas suas primeiras etapas.

- O processo de individuação dá-se por várias etapas em que o eu (o centro da consciência) integra de forma consciente alguns aspectos inconscientes da psique (os arquétipos persona, sombra, anima/animus $\mathrm{e}$, enfim, o self).

$\mathrm{O}$ processo de individuação é, portanto, uma integração entre consciente (cujo núcleo central é o $\mathrm{eu}$ ) e inconsciente (cujo núcleo central é o self). A pessoa passa a viver a partir de um núcleo central psíquico que tem como "comando" um self consciente.

- Para Jung o inconsciente (através da ação do self) impele todas as pessoas a viverem o processo de individuação. No entanto, a maioria delas foge dessa busca (pois essa busca implica no enfrentamento de si mesmo, de seu lado "sombrio" e de suas próprias contradições e complexos - traumas psicológicos).

Nada afirma que um indivíduo irá chegar ao objetivo final do processo de individuação, ou seja, a vivência plena do self. isso depende de fatores internos (do psiquismo da pessoa, de sua capacidade de enfrentamento de si mesmo, de suas contradições) e de fatores externos (das possibilidades e limites dados pelo meio em que o indivíduo vive). 
Jung constatou que a não vivência dessa busca faz dos indivíduos seres autômatos (máquinas), egoístas (prejudiciais, portanto, à vida em sociedade) ou os leva ao sofrimento psíquico (neuroses), uma vez que a vida com o passar dos anos acaba por perder seu sentido, se este não for buscado (Jung afirma que o aspecto material da vida é apenas um dos pólos necessários para vivê-la. O outro pólo é o aspecto espiritual. Uma vida sadia deve integrar a vivência de seus aspectos materiais e espirituais. A pessoa que se volta apenas para a vivência dos aspectos materiais da vida mais cedo ou mais tarde irá deparar-se com dois caminhos: ou torna-se um ser "autômato", uma pessoa que "vegeta", alguém prejudicial à sociedade, que não se importa com os outros, ou fatalmente adentrará o caminho do sofrimento psíquico (neuroses), pois a busca da vivência do self é uma herança herdada da humanidade que insiste para ser concluída em cada um de nós.

Jung também relata que o fato de uma pessoa atingir a idade senil (sua "velhice") não necessariamente implica no fato de ter alcançado a vivência do self . A maior parcela da humanidade chega à morte sem ter concluído seu processo de individuação.

Para a maioria das pessoas, observa Jung, o início do processo de individuação (quando ocorre) dá-se por volta dos 30 anos, idade em que freqüentemente acontece a "crise da meia idade" (a pessoa sente que não é mais criança, não é mais jovem, sente que inicia seu processo de envelhecimento, muitas vezes já é pai ou mãe, pode ter perdido entes queridos. Entre outros fatos, tais fatores levam o ser humano à busca de um sentido para a vida e para a morte, daí o início do processo de individuação).

$\mathrm{Na}$ nossa sociedade, devido às crises (de valores, sociais, econômicas, etc.) que estamos passando na atualidade, muitas pessoas fogem de seu real processo de individuação e vão procurar respostas às suas questões e aos seus sofrimentos psíquicos em "receitas de felicidade" (doutrinas que prometem o "céu", livros que "trazem" soluções para todos os problemas da vida, etc.), ficando sujeitas às várias formas de modismos e charlatanismo presentes na sociedade (no entanto, devemos considerar que há religiões e publicações de caráter idôneo que realmente trazem contribuições para auxiliar o indivíduo no seu caminho pelo processo de individuação).

- Para Jung os mitos são elementos que servem de "marcos", "sinais", para auxiliar as pessoas na busca da vivência do self. Os mitos (expressos em histórias contadas e escritas, nos cantos, nas pinturas, nas esculturas e em todas as formas de arte) trazem símbolos que guardam o conhecimento da história da humanidade na busca da vivência do self. É por isso que em momentos de grandes crises há uma demanda generalizada pelos mitos. Assim, estes ressurgem numa versão atualizada ("Guerra nas Estrelas", "O senhor dos anéis", "O Alquimista", etc.) contando numa "roupagem nova" as velhas histórias sobre a eterna luta entre o bem e o mal, sobre a busca do herói pela cura da doença de seu povo, etc. (Sobre a importância dos mitos como auxiliares no processo de individuação, consultar a obra " $O$ poder do mito" do antropólogo norte americano Joseph Campbell).

- Algumas nações nativas garantiam aos seus membros uma educação contendo elementos míticos, religiosos, passados 
de geração a geração por tradições orais, gestuais e escritas (contação de histórias, rituais, danças, expressões artísticas, etc.), que serviam como "marcos" para a vivência do processo de individuação. Assim, cada membro da tribo (ou do clã, etc.) era educado para buscar a integração com si mesmo, com os outros, com a natureza e com Deus. Daí, o motivo dessas sociedades terem mantido um ótimo estado de saúde mental coletiva (até a chegada do "homem branco").

Nas nossas sociedades modernas a educação perdeu seu sentido mítico: a maioria dos pais não possui vivência do processo de individuação para poderem educar miticamente seus filhos, grande parte das escolas nem sequer indaga sobre a necessidade de uma educação mítica e os meios de comunicação em massa ( $\mathrm{TV}$, rádio, propaganda, etc.) celebram a cultura não da individualidade (que se busca no processo de individuação) mas do individualismo ("cada um por si", "quem pode mais chora menos", "manda quem pode, obedece quem tem juízo"). Por esse motivo, nossa sociedade passa por uma crise de valores, de ausência de sentido para a vida e para a morte, que se reflete em quatro aspectos: primeiro, na existência de uma filosofia materialista, cética, vazia de sentido à vida (niilismo); segundo, numa procura desenfreada das pessoas por "soluções fáceis", "fórmulas mágicas", para resolver essa crise; terceiro, no crescimento do índice de doenças e distúrbios mentais (neuroses, psicoses, dependências ao álcool e outras drogas, ansiedade, depressão, etc.) devido o indivíduo estar cindido dele mesmo e; quarto, em condutas coletivas de violência e desvalorização da vida (não só a do outro, mas a própria. Nesse sentido, não só a vida passa a ser banalizada, mas, também, a própria morte).

- Tal como foi dito anteriormente, o processo de individuação dá-se através de etapas de confrontação do $e u$ com os principais arquétipos que influenciam a consciência: persona, sombra, anima/animus e, enfim, o self.

Os sonhos, de uma forma geral (mas não necessariamente), são mensagens do inconsciente que trazem "mapas" sobre o desenvolvimento do processo de individuação da pessoa. Por isso, a interpretação dos sonhos é um recurso auxiliar da psicoterapia. $\mathrm{O}$ sonho permite ao psicoterapeuta verificar em que etapa do processo de individuação a pessoa se encontra, tendo acesso aos conflitos que se travam entre os vários elementos de sua psique (o enfrentamento de seus arquétipos, de suas contradições e de seus complexos).

Se no plano coletivo os mitos expressam simbolicamente a história do processo de individuação da humanidade, no plano individual são os sonhos que expressam simbolicamente a história do processo de individuação da pessoa. Os mitos são uma expressão dos sonhos no plano coletivo. E os sonhos são uma expressão dos mitos no plano individual.

Para decodificar a simbologia presente nos sonhos e mitos, Jung estudou a fundo os símbolos da mitologia e da alquimia ocidental e oriental.

\section{ETAPAS DO PROCESSO DE INDIVIDUAÇÃO}

\section{O eu}

- É o núcleo central do consciente (responsável pelos mecanismos de percepção, de atenção, de memória e de raciocínio), mantém contato com o 
mundo interior (processos psíquicos, internos) e exterior (meio ambiente, sociedade) do sujeito.

- O processo de individuação dá-se através de etapas de confrontação do $e u$ com os principais arquétipos que influenciam a consciência: persona, sombra, anima/animus e self.

- Nos sonhos o eu se apresenta na imagem do sonhador.

\section{O confronto do eu com a persona}

- O primeiro momento do processo de individuação é o reconhecimento pelo eu da persona. É o momento em que a pessoa toma consciência das "máscaras" que utiliza em sociedade.

- Reconhecer a persona significa viver as "máscaras", desempenhar os papéis sociais impostos pela sociedade sem que se deixe de exercer as qualidades da real personalidade (no dizer de Jung, da alma - não no sentido espiritual).

Quando o indivíduo reconhece sua persona e a integra de forma consciente ao seu eu podemos dizer que o indivíduo pode viver os aspectos positivos desta, adaptando-se mais facilmente às diversas situações sociais sem prejuízo da expressão das qualidades reais de sua personalidade.

- A maioria das pessoas vive sua persona de forma inconsciente e se identificam com ela. Um exemplo clássico é a figura do workaholic (indivíduo "viciado" em trabalho), que muitas vezes identifica-se apenas com os papéis profissionais desempenhados, chegando a sacrificar o relacionamento com a própria família.

Nesse caso, a persona toma uma forma negativa, impedindo que a pessoa viva aspectos de sua personalidade que lhe são necessários a uma vida saudável.

- Grande parcela das pessoas interrompe seu processo de individuação ao se deparar com sua persona, pois resistem em tirar suas "máscaras" perante si mesmas e perante os outros (uma freqüente causa de neurose para o indivíduo é o fato de a própria sociedade lhe retirar as "máscaras").

\section{O confronto do eu com a sombra}

- O segundo momento do processo de individuação é o reconhecimento pelo eu da sombra. É o momento em que a pessoa toma consciência de suas qualidades positivas e negativas inconscientes.

- Reconhecer os aspectos positivos da sombra significa reconhecer em si virtudes que eram desconhecidas (altruísmo, dedicação, voluntariedade, etc.).

- Reconhecer os aspectos negativos da sombra significa olhar para o "fundo do espelho" e se defrontar com os aspectos "negros", "sombrios" da personalidade (inveja, egoísmo, ciúme doentio, ódio, mesquinhez, mentiras, falsidades, etc.).

A maioria das pessoas vive sua sombra de forma inconsciente e a projeta nos outros (sempre o outro é que é o mentiroso, o invejoso, o egoísta, etc.).

Reconhecemos que os outros são capazes de fazer atos mesquinhos porque nós mesmos (pela ação de nossa sombra) somos capazes de fazer esses atos.

- Quando o indivíduo reconhece sua sombra e a integra de forma consciente ao seu $e u$ adquire o conhecimento de suas virtudes e defeitos, o que favorece o desenvolvimento de um melhor convívio com si mesmo e com as demais pessoas.

- Grande parcela das pessoas interrompe seu processo de individuação ao se deparar com sua sombra, pois "ver no fundo do espelho" e reconhecer o lado 
"negro", "sombrio" , da própria personalidade constitui um desafio em que a maioria das pessoas foge.

- Nos sonhos a figura da sombra é personificada numa pessoa do mesmo gênero do sonhador.

\section{O confronto do eu com a anima}

- No processo de individuação, para o homem, após seu eu integrar a persona e a sombra, confronta-se com sua anima.

- A anima é a personificação de todas as tendências psicológicas femininas na psique do homem - as fantasias eróticas, os humores e sentimentos instáveis, as intuições proféticas, a receptividade ao irracional, a capacidade de amar, a sensibilidade à natureza e, por fim, mas nem por isso menos importante, o relacionamento com o inconsciente.

- O homem cujo eu integrou conscientemente sua anima adquire o potencial de melhor lidar com seus sentimentos, de melhor se relacionar com a mulher (inclusive na escolha da parceira ideal) e abre o caminho para a vivência do self (esses são aspectos positivos da anima).

- O homem cujo eu não integrou conscientemente sua anima torna-se presa dela, estando sujeito à imaturidade afetiva (infantilismo), explosões sentimentais, flutuações de humor, dependência, etc.

Por estarem subjugados ao poder da anima tais homens freqüentemente são "usados" por mulheres do tipo femme fatale ("misteriosa, provocadora, atraente, caprichosa, mas, dentro dela, sempre a arder o fogo violento que destrói os homens") ou se relacionam com mulheres do tipo "mãe".

$O$ poder de influência da anima de uma mulher pode passar desapercebido por um homem (principalmente se este nutrir uma paixão por ela: "Ficou cego pela paixão!"), porém, é facilmente percebido por outra mulher. As mulheres conhecem os "segredos, artifícios" da anima de outra mulher.

- Nos sonhos a anima pode se personificar na figura de uma mulher desconhecida ou conhecida (principalmente na imagem da mulher amada) e representar seus aspectos negativos ou positivos (o reconhecimento de que a anima se apresenta de forma negativa ou positiva num sonho só pode ser feito através de sua análise).

\section{O confronto do eu com o animus}

- No processo de individuação, para a mulher, após seu eu integrar a persona e a sombra, confronta-se com seu animus.

- O animus é a personificação de todas as tendências psicológicas masculinas na psique da mulher - aparece mais como uma convicção secreta, "sagrada". Quando uma mulher anuncia tal convicção com voz forte, masculina e insistente ou a impõe às outras pessoas por meio de cenas violentas, reconhece-se, facilmente, a sua masculinidade encoberta. No entanto, mesmo em uma mulher que exteriormente se revele muito feminina o animus pode também ter uma força igualmente firme e inabalável. De repente, podemos nos deparar com algo de obstinado, frio, teimoso e totalmente inacessível em uma mulher (trata-se da manifestação de seu animus).

- A mulher cujo eu integrou conscientemente seu animus adquire o potencial de melhor lidar com sua capacidade reflexiva (livre de juízos infundados, de teimosias, de preconceitos), de melhor se relacionar 
com o homem (inclusive na escolha do parceiro ideal) e abre o caminho para a vivência do self (esses são aspectos positivos do animus).

- A mulher cujo eu não integrou conscientemente seu animus torna-se presa dele, estando sujeita à insegurança pessoal e profissional e à dependência do homem. Torna-se escrava dele, incapaz de traçar seu próprio caminho, expressar sua individualidade.

Por estarem subjugadas ao poder do animus tais mulheres freqüentemente são "usadas" por homens do tipo gigolô ou se "acomodam" às custas de homens do tipo provedor ("pai").

- Nos sonhos o animus pode se personificar na figura de um homem desconhecido ou conhecido (principalmente na imagem do homem amado) e representar seus aspectos negativos ou positivos (o reconhecimento de que o animus se apresenta de forma negativa ou positiva num sonho só pode ser feito através de sua análise).

\section{O confronto do eu com o self (si mesmo)}

- A vivência do self constitui o objetivo do processo de individuação.

- O confronto do eu com o self surge apenas após o primeiro ter se confrontado com a persona, a sombra e a anima (no caso do homem) ou o animus (no caso da mulher).

- Quando o eu incorpora de forma consciente o self, integra-se a ele. Não mais o $e u$, mas o self consciente, passa a ser o "comandante" da psique. A vivência do self traz algo de numinoso, de sagrado, um sentimento de integração com si mesmo, com os outros, com a natureza e com Deus. A vivência do self não exclui a vida material e a sexualidade, muito pelo contrário, integram a vida material e sexual à vida espiritual (esses são aspectos positivos do self).

- O homem (ou mulher) cujo eu ao confrontar-se com o self deixa se subjugar por ele, torna-se um(a) fanático(a) religioso(a), um(a) doutrinador(a), um beato(a). Passa a impôr suas "verdades" religiosas aos outros (esse é o aspecto negativo do self).

- Nos sonhos da mulher o self (enquanto aspecto positivo) geralmente aparece personificado em símbolos como o de uma figura de mulher feminina superior - uma sacerdotisa, uma feiticeira, uma mãe-terra ou deusa da natureza ou do amor. No caso do homem, o self (enquanto aspecto positivo) manifesta-se como um iniciador masculino aos "grandes mistérios ocultos" ou um guardião desses "mistérios" (o guru, dos hindus), um velho sábio, um mago, um espírito da natureza.

$\mathrm{O}$ self também se manifesta em imagens oníricas "fantásticas" (não só nos sonhos, também em visões) repletas de simbologias mitológicas e sagradas (cruzes, pentáculos, círculos mágicos, mandalas, etc.).

- É necessário explicar que a vivência do self não constitui um "permanente estado de felicidade". Implica num sentido de integração com si mesmo, com os outros, com a natureza e com Deus no sentido de uma maior compreensão dos fenômenos da vida e da morte. Inclui o aprendizado da convivência com as mais diversas contradições da vida: alegria e tristeza, amor e ódio, altruísmo e egoísmo, prazer e sofrimento, certezas e dúvidas, vida e morte, etc. A vivência do self integra a vida material e espiritual e confere um sentido sagrado, 
transcendental, à existência, embora não isente o homem de dúvidas e sofrimentos. Isso se faz sentir nas próprias palavras de Jung: "O mundo no qual penetramos pelo nascimento é brutal, cruel e, ao mesmo tempo, de uma beleza divina. Achar que a vida tem ou não tem sentido é uma questão de temperamento. Se o não-sentido prevalecesse de maneira absoluta, o aspecto racional da vida desapareceria gradualmente com a evolução. Não parece ser isso o que ocorre. Como em toda questão metafísica, as duas alternativas são provavelmente verdadeiras: a vida tem e não tem sentido, ou então possui e não possui significado. Espero ansiosamente que o sentido prevaleça e ganhe a batalha."

\section{SINCRONICIDADE}

- Tal como foi mencionado anteriormente, a camada mais profunda do inconsciente coletivo é denominada por Jung de Psicóide. Esta camada se relaciona aos acontecimentos que ultrapassam as explicações cientificamente objetivas sobre as relações causais entre fenômenos psíquicos e físicos. Tais fenômenos possuem uma ligação causa-efeito que desafiam as explicações da física clássica sobre a relação entre a psique, o espaço e o tempo (tratam-se dos fenômenos paranormais, extraracionais).

Dentre esses fenômenos, Jung interessou-se particularmente pelo estudo de uma manifestação a qual denominou sincronicidade (um conceito criado por ele e também estudado por Wolfgang Pauli, um físico agraciado com o Prêmio Nobel de Física. Jung escreveu um livro em que relata e defende a existência de fenômenos de sincronicidade). Se por um lado, no campo do psiquismo a sincronicidade é estudada pela Psicologia Analítica, no campo da física, é estudada pela Física Quântica.

- Jung define sincronicidade como "coincidências" significativas que não podem ser explicadas por uma lei objetiva de causa e efeito. São "acasos" significativos em que os eventos externos, aparentemente dissociados no tempo e no espaço, ligam-se aos nossos estados internos e nos integram a um "todo" maior.

A sincronicidade, em outras palavras, relaciona-se a "coincidências" que não são bem "coincidências", eventos que não ocorrem por "acaso". Possuem um significado psicológico que ultrapassam as explicações objetivas de causa e efeito entre psique, tempo e espaço.

Conferem ao indivíduo um sentimento de estar integrado ao universo, a uma "consciência cósmica", a Deus. A sincronicidade traz, portanto, uma sensação de vivência do sagrado, do numinoso.

- Jung observou em seus pacientes que a sincronicidade costuma ocorrer em circunstâncias de intensidade e agitação emocionais e atinge seu ápice antes de uma ruptura psicológica. Essas situações de "psique estimulada" incluem os principais eventos transformadores da vida, tais como nascimentos, mortes, apaixonar-se ou desapaixonar-se, momentos críticos ou crises pessoais, salvamentos de situações perigosas, viagens, etc.

- A sincronicidade está mais presente na vida da pessoa quando ela se aprofunda no seu processo de individuação. Os "acasos" acontecem de forma que auxiliam na busca da vivência do self.

- Exemplos de sincronicidades: 
- Uma pessoa está falando sobre um amigo que não vê há anos e neste exato momento recebe um telefonema desse amigo.

- Procurando desesperadamente por uma informação ou notícia de que se precisa muito, ela aparece de uma forma inesperada.

- A vivência de "coincidências" que indicam para a tomada de uma determinada decisão.

- A vivência de enfrentamento de um obstáculo após o outro para em seguida se descobrir que não era melhor ter seguido uma decisão inicialmente tomada.

- Pensar em uma pergunta e ela ser respondida pelo rádio, $\mathrm{TV}$ ou uma pessoa ao lado.

- O encontro com pessoas que trazem determinados conhecimentos e propiciam determinadas experiências que nos auxiliam na busca da vivência do self (nesse caso, não só certas pessoas nos servem de "auxiliares" (mesmo que inconscientemente) para a vivência de nosso processo de individuação. Também, mesmo que de forma inconsciente, atuamos como "auxiliares" de outras pessoas para que vivam seu processo de individuação).

\section{MORTE}

- Em sua autobiografia editada post mortem e intitulada "Memórias, sonhos e reflexões" Jung reserva um capítulo intitulado "Sobre a vida depois da morte" para tratar dessa questão.

- Nesse livro Jung deixa "em aberto" a possibilidade da existência da vida após a morte, porém, em outros escritos deixa entrever que acredita nessa possibilidade (particularmente não tenho dúvidas de que Jung acreditava na existência da vida após a morte).

- Jung relata que a ciência tal qual a conhecemos hoje é muito limitada para afirmar ou negar a existência da vida após a morte, entretanto, deixa claro que o fato de as ciências não poder averiguar se tal fenômeno é possível ou não, não significa que esse fenômeno não possa existir. Para Jung a ciência deve ser humilde para aceitar suas limitações: se não pode provar a existência ou inexistência de algo que tenha uma suposta natureza metafísica, não pode, todavia, emitir o juízo final de negação dessa existência.

- Jung ainda menciona que o impulso para a busca pelo sentido da vida e da morte é uma herança da humanidade que se passa de geração a geração e que procura uma resposta em cada indivíduo. Jung conclui que a pessoa deve fazer essa busca mesmo que seus esforços terminem numa confissão de impotência. Para ele, o indivíduo que termina sua vida sem ter feito essa busca sofre uma "grande perda".

Obs.:

- Pelo fato de Jung tratar de assuntos que ultrapassam o limite de uma ciência positivista, meramente "objetiva", ele foi chamado (e ainda o é) por muitos de "pseudocientista", "místico", "esotérico", "doutrinador", entre outras palavras equivocadas.

Jung em momento algum de sua vida teve a intenção de se passar por um doutrinador. $\mathrm{O}$ fato é que sua ciência aborda aspectos do empirismo (experiências de vida, no caso, dele e de seus pacientes), da vida humana, que não foram levados em consideração por outras escolas de Psicologia. 
Portanto, Jung ao formular sua Psicologia Analítica, produziu uma teoria e uma prática com fundamentos científicos. $\mathrm{O}$ empirismo, embora alguns cientistas não concordem, não deixa de ser um método científico. Portanto, chamar Jung de "místico", "esotérico" e "pseudocientista" é um grande equívoco em que apenas seus críticos e vendedores de artigos e serviços esotéricos saem lucrando.

\section{TIPOS PSICOLÓGICOS}

- Apesar de o processo de individuação ser o eixo central da Psicologia Analítica, a estrutura dos tipos psicológicos formulada por Jung é a face mais publicamente conhecida de sua teoria.

Trata-se de um quadro teórico acerca dos tipos de personalidade que traz elementos sobre a psicologia do outro, das suas diferenças, um conhecimento de fundamental importância para a melhoria das relações humanas.

$\mathrm{Na}$ atualidade, há, por exemplo, trabalhos sendo desenvolvidos no campo da administração de pessoas fundamentados na tipologia psicológica estruturada por Jung. Tais atividades estão voltadas para a identificação de potenciais humanos e para o desenvolvimento de equipes.

Procurei nesse tópico apresentar uma síntese das bases teóricas sobre os tipos psicológicos. Para se obter um pouco mais de informações sobre o assunto sugiro a consulta ao livro "Jung: vida e obra", de Nise da Silveira. Para um conhecimento aprofundado sobre o tema, é necessária a leitura do capítulo 10 ("Descrição geral dos tipos") do livro "Tipos Psicológicos" (obras completas, volume 6) de autoria do próprio Jung.

\section{Fluxo de libido: extroversão e introversão}

- Jung indica que a libido (energia psíquica) flui em dois sentidos:

- da extroversão: de dentro para fora da psique

o indivíduo tende a se orientar por fatores objetivos, externos

- da introversão: de fora para dentro da psique

o indivíduo tende a se orientar por fatores subjetivos, internos

- A extroversão e a introversão estão presentes em todas as pessoas de duas formas opostas e complementares:

- como uma orientação principal, diferenciada, de nível consciente

- como uma orientação inferior, indiferenciada, de nível inconsciente

- Assim, se o indivíduo tem no plano consciente a extroversão como sua orientação principal, seu inconsciente terá como função inferior e indiferenciada (mas oposta e complementar à orientação do consciente) a introversão.

Seu consciente é extrovertido, porém, seu inconsciente é introvertido.

- De outra forma, se o indivíduo tem no plano consciente a introversão como sua orientação principal, seu inconsciente terá como função inferior e indiferenciada (mas oposta e complementar à orientação do consciente) a extroversão. 
Seu consciente é introvertido, porém, seu inconsciente é extrovertido.

- É importante esclarecer que não existe um sujeito totalmente extrovertido ou totalmente introvertido. Tal como foi explicado acima, em termos de fluxo de libido o consciente e o inconsciente apresentam características opostas, porém, complementares. Se no plano consciente predomina um determinado tipo de orientação, no plano inconsciente o que se verá é a preponderância da orientação contrária a do consciente. Trata-se de um aspecto de "compensação" próprio da psique

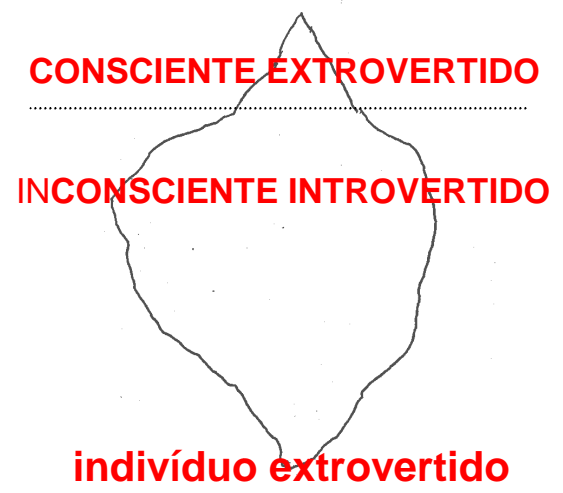

As funções psíquicas: pensamento, sentimento, percepção e intuição

- Jung percebeu que além de a psique possuir dois sentidos de fluxo da libido (extroversão e introversão) também possui quatro funções psíquicas (pensamento, sentimento, percepção e intuição) que também são mecanismos de adaptação do indivíduo à sua realidade subjetiva e objetiva. (um mecanismo psicofisiologicamente herdado) que tem como objetivo a adaptação do indivíduo ao seio meio. Embora uma orientação predomine sobre a outra, as duas estão presentes no sujeito, o que lhe possibilita adaptar-se às exigências postas por seu mundo interior (a realidade subjetiva, psíquica) e por seu mundo exterior (a realidade objetiva, ambiental e social).

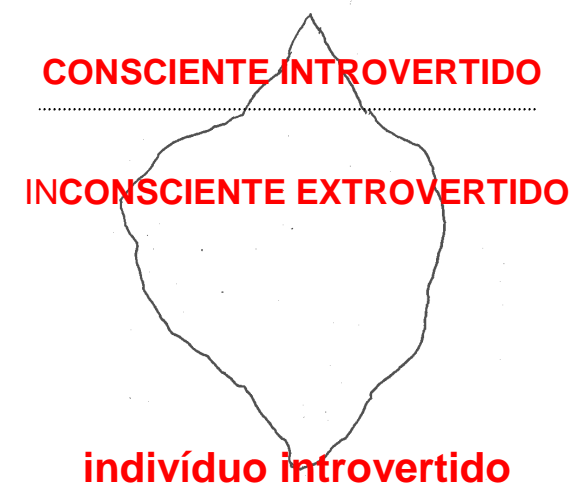


sentimento : faz a avaliação dos objetos. Decide o valor que estes têm para nós (se agradam ou não). Estabelece julgamentos assim como o pensamento, entretanto, obedece a uma lógica toda diferente: sua lógica não é a da razão, é a lógica da emoção.

intuição : é a apreensão perceptiva dos objetos pela via inconsciente. A intuição "vê" a natureza "oculta" das pessoas, dos objetos e dos fatos.

As funções psíquicas formam dois pares de funções opostas, entretanto, complementares:

- o pensamento é oposto, porém, complementar ao sentimento.

- a perceção é oposta, porém, complementar à intuição.

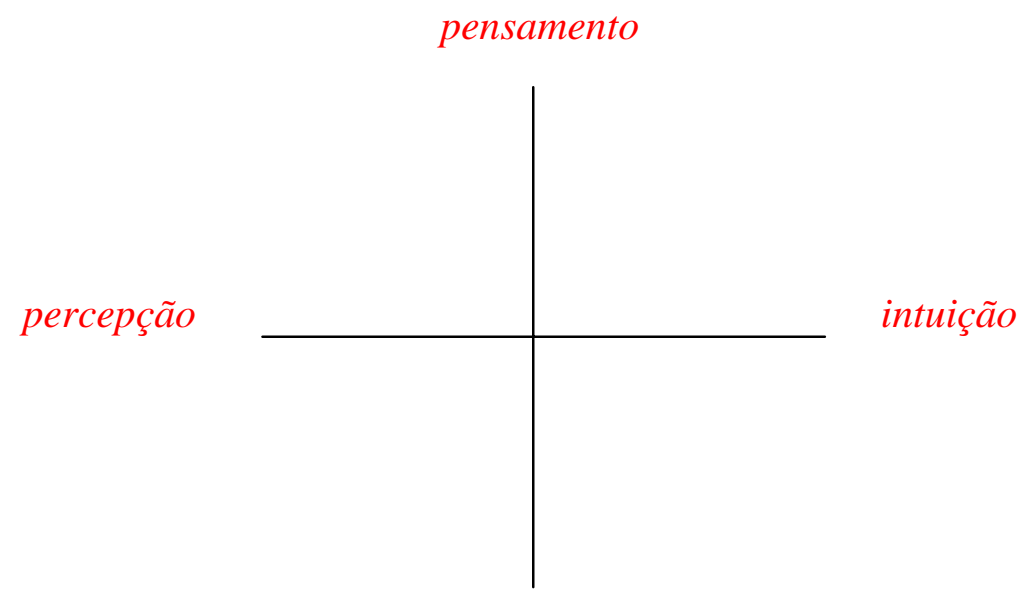

sentimento

Assim como todas as pessoas possuem extroversão e introversão (embora uma predomine sobre a outra), também possuem as quatro funções psíquicas, contudo, em graus diferentes de potencialidade.

- $1^{\circ}$ função psíquica : é a principal, mais desenvolvida, mais diferenciada, utilizada de forma mais consciente

- $2^{\underline{o}}$ função psíquica : é auxiliar da função principal, também age num plano mais consciente 
- $3^{-}$função psíquica : possui um desenvolvime nto rudimentar, agindo num plano mais inconsciente

- 4ํㅡำ funão psíquica : é a inferior, mais indiferenciada , permanecendo num plano quase que exclusivament e inconsciente
Jung menciona que o ideal para a adaptação ao mundo interior e exterior seria que o indivíduo se orientasse de forma equilibrada pela extroversão e introversão, bem como apresentasse suas quatro funções psíquicas em graus de potencialidades equivalentes. Contudo, não é isso o que geralmente ocorre.

Jung também esclarece que o processo de individuação atua de tal forma que o fluxo de libido e as funções psíquicas passam a agir de uma forma mais equilibrada (porém, não totalmente) na psique uma vez que tal processo implica no conhecimento de si mesmo, envolvendo a expressão consciente das diferentes potencialidades da personalidade.

\section{Diagrama dos tipos psicológicos}

\begin{tabular}{|c|c|c|}
\hline \multicolumn{3}{|c|}{ TIPO EXTROVERTIDO } \\
\hline $\begin{array}{c}1^{\underline{0}} \text { função } \\
\text { extrovertida } \\
\text { mais consciente }\end{array}$ & $\begin{array}{c}2^{-} \text {e } 3^{\underline{o}} \text { funções } \\
2^{\mathrm{o}}: \text { extrovertida, mais consciente } \\
3^{\mathrm{o}}: \text { introvertida, mais inconsciente }\end{array}$ & $\begin{array}{c}4^{\underline{0}} \text { função } \\
\text { introvertida } \\
\text { mais inconsciente }\end{array}$ \\
\hline pensamento & percepção ou intuição & sentimento \\
\hline sentimento & percepção ou intuição & pensamento \\
\hline percepção & pensamento ou sentimento & intuição \\
\hline intuição & pensamento ou sentimento & percepção \\
\hline
\end{tabular}

\begin{tabular}{|c|c|c|}
\hline \multicolumn{3}{|c|}{ TIPO INTROVERTIDO } \\
\hline $\begin{array}{c}1^{\underline{0}} \text { função } \\
\text { introvertida } \\
\text { mais consciente }\end{array}$ & $\begin{array}{c}2^{\underline{0}} \text { e } 3^{\underline{0}} \text { funções } \\
2^{\underline{0}}: \text { introvertida, mais consciente } \\
3^{\underline{0}} \text { : extrovertida, mais inconsciente }\end{array}$ & $\begin{array}{c}4^{\underline{0}} \text { função } \\
\text { extrovertida } \\
\text { mais inconsciente }\end{array}$ \\
\hline pensamento & Percepção ou intuição & sentimento \\
\hline sentimento & Percepção ou intução & pensamento \\
\hline percepção & Pensamento ou sentimento & intuição \\
\hline intuição & Pensamento ou sentimento & percepção \\
\hline
\end{tabular}




\section{DESCRIÇÃO BÁSICA DOS TIPOS PSICOLÓGICOS}

\section{TIPOS EXTROVERTIDOS}

\section{Pensativo extrovertido}

- Sua atitude tende constantemente a estabelecer uma ordem lógica entre coisas concretas. $\mathrm{O}$ raciocínio abstrato não os atrai. O gênero masculino é o principal (mas não único) representante desse tipo.

- Esse tipo gosta de fazer prevalecer seus pontos de vista que coordena de maneira rígida e impessoal, tornandose muitas vezes autoritário, principalmente no círculo de sua família.

- Geralmente esse tipo é encontrado nos engenheiros, trabalhadores técnicos, inventores, políticos, comerciantes, administradores, empresários, economistas, advogados, filósofos, sociólogos e psicólogos "positivistas", entre outras profissões.

- O ponto fraco desse tipo é o sentimento.

Embora capaz de ter afeições profundas, tem grande dificuldade de reconhecê-las em si e de expressá-las.

Não é raro que tais indivíduos sejam emocionalmente dependentes $\mathrm{e}$ apresentem súbitas e violentas explosões de afeto (por exemplo, ciúme doentio).

Estes fenômenos são decorrentes de uma função sentimental introvertida, inferior e indiferenciada.

\section{Sentimental extrovertido}

- Mantém adequada relação com os objetos exteriores. É acolhedor e afável. Costuma ter um grande círculo de amigos. O gênero feminino é o principal (mas não único) representante desse tipo.

- Guia-se pelo julgamento emotivo do que lhe agrada ou não no mundo exterior (pessoas ou objetos). Tende a permanecer fiel aos valores sociais que lhe são inculcados desde a infância.

- Esse tipo é geralmente encontrado em socialites, profissionais da moda, modelos, publicitários, arquitetos, donas de casa, entre outras profissões.

- O ponto fraco desse tipo é o pensamento.

Atrás de uma aparente afabilidade, muitas vezes se escondem pensamentos sem juízos fundamentados, reflexões preconceituosas e teimosias.

Quando o controle do sentimento falha, surgem pensamentos de autodesvalorização.

Estes fenômenos são decorrentes de uma função pensativa introvertida, inferior e indiferenciada.

\section{Perceptivo extrovertido}

- Compraz-se na apreciação sensorial das coisas objetivas. Adapta-se facilmente às circunstâncias, possuindo um seguro sentido da realidade. Relaciona-se de modo concreto e prático com os objetos exteriores. Ama os prazeres da vida, o conforto da habitação. É um autêntico bon vivant.

- Esse tipo tem como principais expoentes engenheiros, mecânicos, trabalhadores técnicos, homens de negócios, empresários e comerciantes.

- O ponto fraco desse tipo é a intuição.

Repele qualquer tipo de teoria sobre a natureza dos objetos, apegando-se meramente à descrição dos mesmos.

Quando o controle da percepção falha, de forma inesperada apega-se a idéias místicas de baixo nível, histórias 
extravagantes de fantasmas e as mais diversas superstições, o que muito espanta o observador desprevenido que o considera um realista em potencial.

Estes fenômenos são decorrentes de uma função intuitiva introvertida, inferior e indiferenciada.

\section{Intuitivo extrovertido}

- Consegue perceber as possibilidades futuras, que ainda não assumiram formas definidas no mundo real.

- Esse tipo não gosta de situações estáveis. Devido à visão das diferentes possibilidades que lhe são abertas por sua intuição, tendem a passar a vida "pulando de galho em galho". Outros colhem o que ele planta.

- Os homens de negócio são os principais exemplos desse tipo.

- O ponto fraco desse tipo é a percepção de si mesmo.

Quando o controle da intuição falha, surgem sintomas de hipocondria, fobias e sensações físicas das mais absurdas. Estes fenômenos são decorrentes de uma função perceptiva introvertida, inferior e indiferenciada.

\section{TIPOS INTROVERTIDOS}

\section{Pensativo introvertido}

- Tem atração pelos pensamentos abstratos. Possui uma lógica subjetiva. O gênero masculino é o principal (mas não único) representante desse tipo.

- Alguns exemplos desse tipo são os matemáticos e físicos teóricos, psicólogos, sociólogos e filósofos empiristas, teólogos, entre outras profissões.

- O ponto fraco desse tipo é o sentimento.

Se por um lado consegue perceber seus próprios sentimentos, por outro, não raramente tem uma grande dificuldade de expressá-los. Nele a afetividade toma um caráter profundo. Na sua vida emotiva ama ou odeia. Muitas vezes aparenta possuir uma personalidade fria.

Quando sua lógica, sua razão, falha, confunde-se em seus próprios sentimentos, "perdendo-se" neles. Às vezes, fica à mercê de explosões afetivas ("perdendo a cabeça") e crises de ansiedade. A perda do controle da razão e a submissão aos sentimentos provocam-lhe angústias e irritabilidade. Estes fenômenos são decorrentes de uma função sentimental extrovertida, inferior e indiferenciada.

\section{Sentimental introvertido}

- Esse tipo é geralmente identificado em mulheres. Tendem a ser calmas, retraídas e silenciosas. São pouco abordáveis e difíceis de compreender porque, sendo dirigidas pelo sentimento introvertido, suas verdadeiras intenções permanecem ocultas. São verdadeiros "enigmas".

Nutrem sentimentos secretos e internos, mas dificilmente os exprime externamente, guardando-os para si (o que pode se tornar uma fonte de sofrimento psíquico, neuroses).

As relações com o objeto amado são mantidas dentro de limites bem medidos. Toda manifestação emocional exuberante vinda do objeto pode lhe desagradar e provocar reações de repulsa, irritabilidade.

Vista do exterior, pode parecer fria, quando na realidade oculta grandes paixões.

- O ponto fraco desse tipo é o pensamento.

Costumam ler muito e guardar várias informações, porém, têm dificuldade de estruturá-las de forma teórica, 
produzindo construções intelectuais pobres e toscas.

Tendem a explicar as coisas por um único pensamento diretor, muitas vezes mesclado de preconceitos, juízos infundados e teimosias.

Por normalmente julgarem-se sempre corretas, não raramente apresentam um comportamento autoritário, impositivo. É freqüente que se preocupem com o que os outros pensam delas, atribuindo a esses outros, pela projeção de pensamentos negativos, julgamentos críticos, rivalidades e intrigas.

Estes fenômenos são decorrentes de uma função pensativa extrovertida, inferior e indiferenciada.

\section{Perceptivo introvertido}

- Cinge-se à percepção do que acontece em si (psíquica e fisiologicamente).

- Possui um admirável juízo estético, apreciando com requintada sutileza as formas, cores e perfumes.

- O ponto fraco desse tipo é a intuição. Quando a percepção falha, torna-se vítima de neuroses obsessivas, neurastenias e hipocondria.

Estes fenômenos são decorrentes de uma função intuitiva extrovertida, inferior e indiferenciada.

\section{Intuitivo introvertido}

- "Vê" a fundo o mundo subjetivo pois está intimamente ligado aos arquétipos, ao inconsciente coletivo, de tal forma que chega a viver muito pouco a realidade objetiva. É um indivíduo ensimesmado.

- Faz o tipo "viajante". Geralmente segue o caminho das artes. Nesse tipo também se encontram os "profetas" e "visionários".

- O ponto fraco deste tipo é a percepção da realidade objetiva.
Quando o controle da intuição falha, surgem sintomas de neuroses obsessivas, neurastenias e hipocondria. Estes fenômenos são decorrentes de uma função perceptiva extrovertida, inferior e indiferenciada. 


\section{BIBLIOGRAFIA}

BELITZ, Charlene; LUNDSTROM, Meg. $O$ poder do fluxo: formas práticas de transformar sua vida com coincidências significativas. Tradução: Laura Neves. Rio de Janeiro: Rocco, 2000. 276p. Título original: The power of flow: practical ways to transform your life meaningful coincidence. (Coleção Arca do Tempo).

CAMPBELL, Joseph. O poder do mito. 14. ed. Tradução: Felipe Moisés. São Paulo: Palas Athena, 1996. 247p. Título original: The power of myth.

JUNG, Carl G. Memórias, sonhos e reflexões. 21. ed. Tradução: Dora Ferreira da Silva. Rio de Janeiro: Nova Fronteira, 2000. 361p. Título original: Memories, dreams and reflections.

- Tipos psicológicos. Tradução: Álvaro Cabral. Petrópolis: Vozes, 1991. 560p. Título original: Psychologische Typen.

JUNG, Carl G et al. O homem e seus símbolos. 14. ed. Rio de Janeiro: Nova Fronteira, 1996. 316p. Título original: The man and his symbols.

ROOB, Alexander. Alquimia e misticismo: o museu hermético. 2. ed. Tradução: Teresa Curvelo. Köln, Alemanha: Taschen, 2001. 711p.

SILVEIRA, Nise da. Jung: vida e obra. 18.ed. Rio de Janeiro: Paz e Terra, 2001. 209p. (Coleção Vida e Obra). 


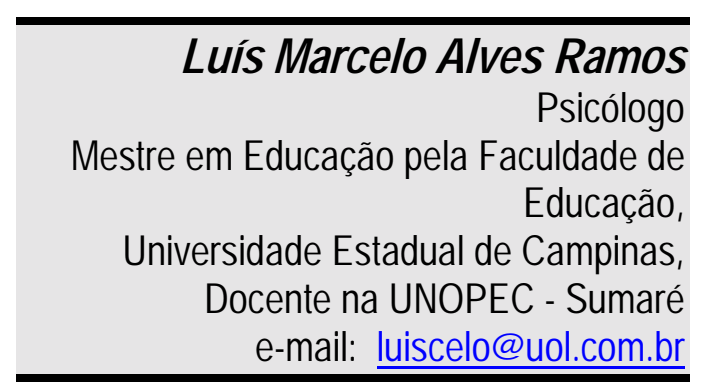

Artigo aceito em 13/12/2002 